\title{
A Comparison of Average Variable Costs of Private vs. Public Land Ranches in Southeastern Montana
}

\author{
JOHN R. LACEY AND JOHN P. WORKMAN
}

\begin{abstract}
A study was conducted in southeastern Montana to determine the effects of federal range grazing on cattle ranch average variable operating costs per animal unit. Data were obtained through personal interviews in 1980 with 68 ranches in six southeastern Montana counties. T-tests were used to determine if the average variable costs per animal unit were less on ranches that rely on federal ranges than on ranches that do not. Annual variable costs per animal unit averaged $\$ 158$ and $\$ 144$, respectively, for ranches obtaining $0-4 \%$ and $5-51 \%$ of total forage from federal lands. However, this difference was not statistically significant. Regression analysis did indicate that variable costs per animal unit were significantly affected by the percentage of total ranch income from crop sales.
\end{abstract}

It has been estimated that $45 \%$ of Montana's ranchers will be out of business by 1990 and 1 in 10 is not expected to survive through 1986 (Governor's Council on Economic Development 1985). Ranch production costs commonly exceed gross revenues.

Both ranchers and agricultural lenders need a better understanding of the factors that influence livestock production costs. Federal rangelands in the western US are one potentially important factor. More than half of the total land area in several western states is in federal ownership and livestock grazing has long been a major use of much of this land. A number of studies have compared grazing fees on private land with those on public land (Nielsen 1982) but little effort has been devoted to determining the effects of public land grazing on average variable costs of livestock production. If federal land grazing fees are significantly lower than private land fees, it seems likely that total variable costs per animal unit (AU) would be less on ranching operations that rely on federal ranges for a significant percentage of their total forages.

The purpose of this analysis was to determine if the average variable cost per $\mathrm{AU}$ is less on ranches that rely heavily on federal ranges than on ranches where federal range supplies only a small percentage of the total forage requirement. Results should be helpful to ranchers and agricultural lenders by providing additional insight into the factors affecting livestock production costs.

\section{Methods}

Six counties in southeastern Montana were selected as the study area (Fig. 1). These 6 counties represent the main range livestock area served by Agricultural Research Service, Sidney, Montana, sponsor of the study (Lacey et al. 1985). Cash receipts from the sale of livestock accounted for $79 \%$ of the total agricultural earnings in that region in 1979.

Bureau of Land Management lands in southeastern Montana are generally "Section 3" lands intermingled in a checkerboard pattern with private holdings. Although FS lands in the study area are blocked into units, most National Forest permittees border the respective forests. Thus, in the study area, little livestock trucking is required by federal permitees.

Possible respondents were identified by reviewing personal

\footnotetext{
Authors are extension range specialist, Cooperative Extension Service, Montana State University, Bozeman 59717; and professor of range economics, Range Science Department, Utah State University, Logan 84322. At the time of the research, the senior author was graduate research assistant, Range Science Department, Utah State University.

Manuscript accepted 16 December 1985.
}

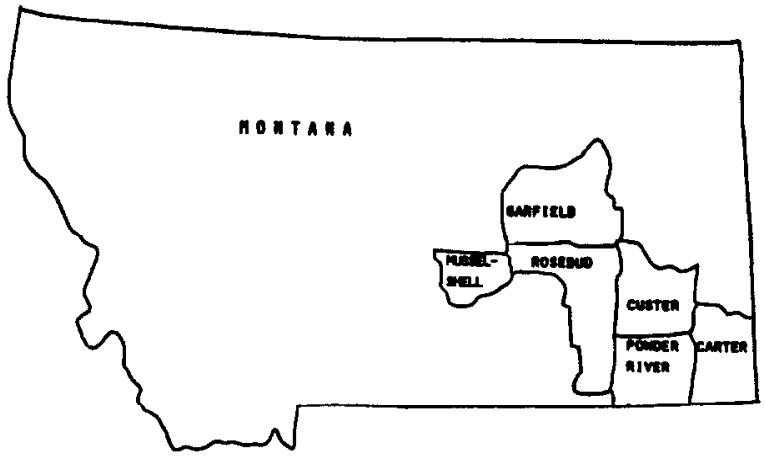

Fig. 1. Map of Montana showing counties included in the study.

property tax records in July, 1979. Names and addresses were recorded of 1,450 operators in the 6-county area who paid taxes on at least 25 head of cattle and/or 50 sheep.

A two-phase sampling technique was used. First, questionnaires were mailed to a total of 830 ranchers during May 1980 . The size of these operations ranged from 50 to 2,096 animal units. In this study an animal unit was defined as one $1,000-\mathrm{lb}$ cow or her equivalent. The ranchers were asked to return the questionnaires and indicate whether they would be willing to discuss the economics of their ranching operation in personal interviews. Eighty-five cattle ranchers were then selected from among those willing to participate. It should be noted that this possibly introduced some nonparticipant bias. Participants were interviewed during July through September, 1980. Their cattle operations ranged from 76 to 1,669 animal units. Incomplete data and/or atypical operations (those with $50 \%$ or more of their income from purebred or farming operations) made it necessary to exclude some of the personal interviews from the final analysis. Therefore, the results reported in this paper are based on data collected during personal interviews with 68 ranch operators.

Forty-six of the ranchers interviewed had BLM permits, while 6 had permits to graze on National Forests (Table 1). Three additional ranchers had both BLM and FS grazing permits. Two

Table 1. Number of federal grazing permits held by 68 ranches in southeastem Montana, 1979.

\begin{tabular}{lc}
\hline Agency Controlling Permit & Number of Ranches \\
\hline BLM & 46 \\
BLM and US Fish \& Wildlife Service & 2 \\
BLM and FS & 3 \\
FS & 6 \\
None & $\frac{11}{68}$ \\
\hline
\end{tabular}

others grazed on both the Charles M. Russell Wildlife Refuge and BLM lands. The contribution of federal range to the total forage used in the ranching operations ranges from 0 to $51 \%$.

The ranchers supplied production and cost data. Cost data were divided into fixed and variable costs. Fixed costs are those 
related to the fixed factors of production and in this study included the opportunity cost of family labor and interest attributed to land investment. Fixed costs do not change with the level of output and cannot be avoided in the short-run. Fixed costs were not included in the analysis.

Variable costs are those associated with the variable factors of production such as purchased feed, repairs, gasoline, grazing fees, interest on operating loans, veterinary bills, and hired labor. Total variable costs increase with increases in production and decrease with reductions in output.

\section{Variable Cost Comparison Using t-Tests}

The variable costs per animal unit on 34 ranches were federal lands provided an average of $22 \%$ of total forage were compared to the variable cost per animal unit on 34 ranches where federal lands provided an average of $1 \%$ of total forage. The amount of federal forage relative to total forage ranged from 5 to $51 \%$ and 0 to $4 \%$, respectively, for the two groups. A t-test was used to test for statistical difference between sample means of variable costs $t$ for the two groups.

Because the above analysis examined a continuum $(0-51 \%$ federal forage contribution) of ranches, rather than two distinct groups (principally private vs "major" dependence on public grazing) a second t-test was conducted. A subsample of 34 ranches was selected from the original 68 observations. Seventeen of the ranches had $1 \%$ or less of their total forage supplied by federal range while the other 17 ranches had $18 \%$ or more. The $t$-test was used to determine if there was any difference in the variable costs per animal unit between the 17 ranches where federal lands provided an average of $0.4 \%$ of total forage and the 17 ranches where the federal lands provided an average of $31 \%$ of the total forage.

\section{Linear Regression Analysis}

Simple linear regression analysis was used to determine the effects of range size, relative importance of crop production, and relative importance of range forage on variable costs per $\mathrm{AU}$. Average variable cost per $\mathrm{AU}$ was the dependent variable in each regression, while the independent variables were number of animal units, percentage of total ranch income from crop sales, and percentage of total forage contributed by range, respectively. Each analysis included 68 observations.

\section{Results and Discussion}

\section{Variable Cost Comparison Using t-Tests}

Annual variable costs per AU ranged from $\$ 52$ to $\$ 361$ and averaged \$151. About one-half of these costs are attributable to 4 items: supplemental feed, machine operation, equipment repair, and interest on operating capital (Table 2). Although variable costs were similar between the 2 ranch groups, costs of machine operation and equipment repair averaged about $\$ 5$ per AU higher on the private land ranches. Average operating loan interest per $\mathrm{AU}$ was also higher on the ranches with less federal range due, perhaps, to their relatively greater crop production. In contrast, average costs of supplemental feed and hired labor were higher on ranches with more federal grazing.

Total annual variable costs per animal unit averaged $\$ 157.86$ for the ranches who 0 to $4 \%$ federal forage compared to $\$ 144.09$ for the ranches that had 5 to $51 \%$ of their forage supplied by federal lands (Table 2). There was no significant difference in variable costs per $\mathrm{AU}$ between the 2 groups at the .05 level. Figure 2 illustrates that the average variable cost per $\mathrm{AU}$ would have had to differ by about $\$ 45$ between the 2 groups for the difference to be statistically significant at the $5 \%$ level.

Similar results were obtained for the subsample comparing 34 ranches. Variable costs per AU averaged $\$ 149.16$ on the 17 ranches with less than $1 \%$ of total forage supplied by federal range, compared to $\$ 148.20$ on the 17 ranches relying on federal range for 18 to $51 \%$ of their total forage (Table 3 ). This difference was not statistically significant at the .05 level.
Table 2. Mean variable cost per animal unit on two groups of ranches in southeastern Montana.

Percent of Total Forage Supplied by Federal Range

\begin{tabular}{lcc} 
& $0-4 \%$ & \multicolumn{2}{c}{$5-51 \%$} \\
Variable Cost Item ${ }^{1}$ & \multicolumn{2}{c}{ Dollars per $\mathrm{AU}^{2}$} \\
\hline Supplemental feed & 24.86 & 30.24 \\
Veterinary & $(16.21)$ & $(24.40)$ \\
& 2.82 & 3.16 \\
Insurance & $(1.46)$ & $(2.16)$ \\
Hired labor & 4.70 & 3.71 \\
& $(3.3)$ & $(2.62)$ \\
Tax (personal property) & 8.33 & 14.77 \\
& $(13.26)$ & $(18.92)$ \\
Fertilizer and seed & 13.16 & 13.08 \\
& $(6.46)$ & $(9.08)$ \\
Machinery operating & 10.99 & 6.83 \\
& $(13.21)$ & $(14.89)$ \\
Equipment repair & 20.79 & 18.81 \\
& $(11.93)$ & $(12.58)$ \\
Utilities & 13.39 & 10.61 \\
& $(8.37)$ & $(6.80)$ \\
Grazing fees & 4.75 & 4.01 \\
& $(2.99)$ & $(2.16)$ \\
Supplies & 10.81 & 9.10 \\
& $(14.49)$ & $(6.59)$ \\
Interest (operating loan) & 7.76 & 8.44 \\
& $(7.52)$ & $(6.82)$ \\
Miscellaneous & & 14.32 \\
& 23.85 & $(14.87)$ \\
TOTAL & $(19.33)$ & 7.01 \\
& 11.65 & $(9.70)$ \\
\hline
\end{tabular}

IVariable costs are for $1979 ; 34$ ranches in each group.

2 Mean standard deviations are in parentheses.

${ }^{3}$ Miscellaneous includes contract labor, building repair, irrigation, herbicide, transportation and accounting.

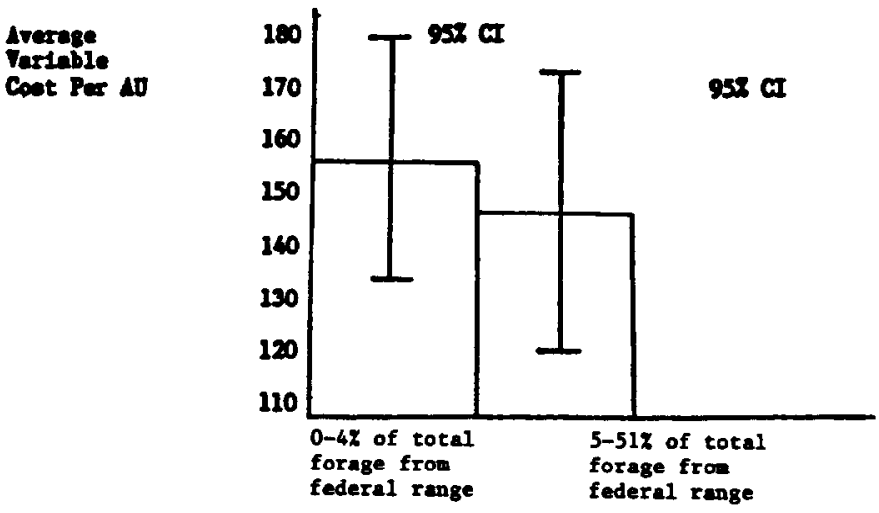

Fig. 2. Average variable cost per AU for two groups of Montana ranches, 1979.

\section{Linear Regression Analysis}

Ranch size (number of AU's) did not affect variable cost per AU. The 34 ranches obtaining only $0-4 \%$ of their forage from federal range averaged $420 \mathrm{AU}$, while the average size of the 34 ranches that had 5-51\% of total forage supplied by federal range was 465 AU. Similarly, the 17 ranches in the subsample that obtained $1 \%$ or less of their total forage from federal range averaged $266 \mathrm{AU}$, compared to $409 \mathrm{AU}$ for the 17 ranches obtaining at least $18 \%$ of total forage from federal range (Table 3). However, the correlation between average variable cost per $\mathrm{AU}$ and number of animal units was not statistically significant (probability of a larger value was $.41)$. 
Table 3. Mean variable cost per animal unit, number of animal units and percent of total income from sale of livestock on two groups of ranches in southeastern Montana.

\begin{tabular}{|c|c|c|c|}
\hline $\begin{array}{l}\text { Range Group' } \\
\text { (Federal Forage Contribution) }\end{array}$ & $\begin{array}{l}\text { Average } \\
\text { Cost Per } \\
\text { AU }(\$)^{2}\end{array}$ & $\begin{array}{l}\text { Number of } \\
\text { Animal Units }\end{array}$ & $\begin{array}{l}\text { Percent of } \\
\text { Total Income } \\
\text { From Sale } \\
\text { Livestock }\end{array}$ \\
\hline Less than $1 \%$ & $\begin{array}{r}\$ 149.16 \\
(51.60)\end{array}$ & $\begin{array}{c}266 \\
(211)\end{array}$ & $\begin{array}{c}85 \\
(19)\end{array}$ \\
\hline 18 to $51 \%$ & $\begin{array}{r}\$ 148.20 \\
(72.00)\end{array}$ & $\begin{array}{c}409 \\
(258)\end{array}$ & $\begin{array}{c}90 \\
(14)\end{array}$ \\
\hline
\end{tabular}

Variable costs are for 1979; 17 ranches in each group.

2Mean standard deviations are in parentheses.

Livestock sales accounted for $87 \%$ of total cash receipts earned by the 68 ranches. But livestock sales accounted for $82 \%$ and $91 \%$ of the total cash receipts earned by the ranches with $0-4 \%$ and $5-51 \%$ federal range forage, respectively. Therefore crop sales made a relatively larger contribution to revenues on the private land operations. In the following linear regression, coefficients were statistically significant $(p<.01)$ and $r^{2}=0.41$ : average variable cost $/ \mathrm{AU}=117.8+2.5$ (percent of total ranch income from sale of crops). The regression equation can be used to predict how production costs of the 2 groups of ranches were affected by percent of income contributed by crops. For each additional percent of crop income contribution, variable cost per AU would increase by $\$ 2.50$. Because private land ranchers earned $9 \%$ more of their total income from crop production than did the average public rancher, their average variable costs per $\mathrm{AU}$ were $\$ 22.50$ higher. Thus, after adjusting for differences in crop income contribution, average variable cost per animal unit was actually only $\$ 135.36$ on the ranches with 0 to $4 \%$ federal forage, or about $\$ 10 / A U$ less than on the ranches more heavily dependent on federal range. While not statistically significant, these differences in variable costs agree with results reported by Torell et al. (1986) for Nevada.

Correlation between average variable cost per $\mathrm{AU}$ and percentage of total forage contributed by range was not statistically significant (probability of a larger value was .44). This nonsignificant correlation is surprising in view of the substantial machinery and labor costs associated with both hay harvest and hay feeding. Variability among ranches in amounts of hay harvested and hay purchased may explain the unexpected low correlation of these variables.

\section{Comparison of Production Practices}

Although the differences are not statistically significant, management practices may be less intense on ranches that are more heavily dependent on federal grazing permits. The average stocking rate was 18.9 ha $(46.7 \mathrm{ac})$ of total (deeded and public) range/ AU on ranches with $22 \%$ federal forage (Table 4) compared to

Table 4. Average stocking rate, calf crop percentage and weaning weight of steer calves on two groups of ranches in southeastern Montana, 1979.1

\begin{tabular}{lccc}
\hline \hline $\begin{array}{l}\text { Ranch Group } \\
\text { (Federal Forage }\end{array}$ & $\begin{array}{c}\text { Stocking } \\
\text { Rate } \\
\text { Contribution) }\end{array}$ & $\begin{array}{c}\text { Calf Crop } \\
\%\end{array}$ & $\begin{array}{c}\text { Weaning } \\
\text { Weight } \\
\text { kg }\end{array}$ \\
\hline $0-4 \%$ & 15.7 & 88 & 202 \\
& $(6.2)$ & $(7.4)$ & $(18.2)$ \\
$5-51 \%$ & 18.9 & 84 & 200 \\
& $(6.0)$ & $(8.4)$ & $(18.2)$ \\
\hline
\end{tabular}

1 Mean standard deviations are in parentheses.

234 ranches in each group.

15.7 ha $(38.8 \mathrm{ac})$ of total range/AU on the ranches with only $1 \%$ federal forage. The higher stocking rate by the latter group may be partially due to more intensive use of range improvement practices (Table 5) and partially due to differences in land productivity. Ranches with $1 \%$ federal range averaged 1 water development for $218.5 \mathrm{ha}(695 \mathrm{ac})$ and $1.6 \mathrm{~km}(1 \mathrm{mi})$ of fence per $94.8 \mathrm{ha}(234 \mathrm{ac})$, while ranches with $22 \%$ federal range averaged 1 water development per $311 \mathrm{ha}(768 \mathrm{ac})$ and $1.6 \mathrm{~km}(1 \mathrm{mi})$ of fence per $112.2 \mathrm{ha}$ (277 ac) of rangeland. Calf crop percentage was $88 \%$ on the ranches

Table 5. Number of hectares per range improvement unit on two groups of ranches in southeastern Montana!

\begin{tabular}{lcc}
\hline \hline & \multicolumn{2}{c}{ Ranch Group ${ }^{2}$} \\
\cline { 2 - 3 } Kind of Improvement & $0-4 \%$ & $5-51 \%$ \\
Wederal foragege & Federal forage \\
\hline Water developments & \multicolumn{2}{c}{ Hectares } \\
\cline { 2 - 3 } wells, springs \& reservoirs (each) & 281 & 311 \\
& $(252)$ & $(241)$ \\
Fence $(1.6 \mathrm{~km})$ & 94.8 & 112 \\
& $(45.3)$ & $(44)$ \\
\hline
\end{tabular}

1 Mean standard deviations are in parentheses.

234 ranches in each group

with $1 \%$ federal range and $84 \%$ on ranches with $22 \%$ federal range (Table 4). Likewise, weaning weights of steer calves were $202 \mathrm{~kg}$ $(445 \mathrm{lb})$ on ranches with little federal range and $200 \mathrm{~kg}(441 \mathrm{lb})$ on ranches more dependent on federal range allotments. Death loss of cows averaged $2.6 \%$ on both groups of ranches. Death loss of calves was $6 \%$ on ranches with little federal range and $9 \%$ on ranches more dependent on federal range.

\section{Summary and Conclusions}

A study was conducted in southeastern Montana to determine whether or not the average variable operating cost per animal unit is less on ranches that rely on federal range than on those that graze little or no federal range. Data were obtained through personal interviews in 1980 with 68 ranches in 6 southeastern Montana counties. The sample was divided into 2 groups of 34 ranches each. One group obtained from 0 to $4 \%$ of total forage from federal ranges while the second group obtained from 5 to $51 \%$ of total ranch forage from federal lands. Annual variable costs per animal unit averaged $\$ 158$ for the private land group of ranches and \$144 for the ranch group more dependent on federal ranges. However, this difference was not statistically significant. Analysis of a subsample comparing 17 ranches with less than $1 \%$ federal forage and 17 ranches with at least $18 \%$ federal forage also yielded no significant differences in average variable costs per AU. However, variable costs per AU did increase significantly with the percentage of total ranch income contributed by crop sales.

\section{Literature Cited}

Governor's Council on Economic Development. 1985. Montana Department of Agriculture in Coordination with the Montana Banker's Association, Helena, Mont.

Lacey, John R., J. Ross Wight, and John P. Workman. 1985. Investment tationale for range improvement practices in eastern Montana. J. Range Manage. 38:2-6.

Nielsen, Darwin B. 1982. Grazing fees for public lands: what's fair? Utah Science 43:1-5.

Torell, L. Allen. E. Bruce Godfrey, and Darwin B. Nielsen. 1986. Forage utilization cost differentials in a ranch operation: a case study. J. Range Manage. 39:34-39. 